\title{
Preparing graduates with the employability skills for an unknown future: Reflection on assessment practice during COVID-19
}

\begin{abstract}
Purpose: The purpose of this paper is to present a reflection of how a student-created video experienced during the mass transition to a fully online environment in response to COVID-19, has brought to light the significance of our prior decisions to integrate employability skills development as part of our accounting subject assessment
\end{abstract} task.

Design/methodology/approach: Due to the short rollout period and pivot to online learning, there has not been an opportunity to undertake a comprehensive and formal data collection. However, anecdotal evidence has been collected from students and staff on the experience of the student-created video assignment in a completely online environment.

Findings: A reflection piece provides an authentic and relevant way of sharing our realisation of the significance of integrating employability skills in assessment practice. This is supported from the anecdotal evidence received from students, which show that the inclusion and assessment of employability skills has provided them with an artifact that demonstrates the employability skills required for the continually changing future and workplace. For staff, the ability to assess and give feedback on the acquisition of employability skills makes it a more enjoyable experience.

Practical implications: This paper enables us to share our experiences and the provision of our resources so that other teaching academics are able to design their own assessment task that contributes to students' acquisition, development and enhancement of employability skills.

Originality/value: The originality of this paper is the application of integrating employability skills in assessment practice and the associated rubric as a way to build students' employability skills in the post-COVID world.

Keywords: video assessment, employability skills, authentic assessment, generic skills, oral communication skills, teamwork skills

Paper type: Expedite Special Issue: Business Teaching Practice: Pivot in COVID-19 


\section{Introduction}

The expectation that higher education accounting curriculum include employability skills development alongside traditional accounting discipline knowledge and technical skills development is well established. Despite this expectation, industry and employers report that accounting education does not adequately equip accounting graduates with employability skills. For this reason, over the last few years, we had made the decision to integrate employability skills development as part of our accounting subject assessment. Yet, the significance of our prior decisions was brought to light during the mass transition to a fully online environment across the world in response to the restrictions imposed upon teaching precipitated by COVID-19. The purpose of this paper is to present a reflection and sharing of our resources to demonstrate how a student-created video assignment introduced in an accounting subject prior to the changes brought on by COVID-19 has been experienced during remote online teaching and learning format. While this assessment task was not designed specifically as a response to remote learning precipitated by the COVID-19 pandemic, it has shown that by giving students the opportunity to acquire, develop and demonstrate a range of employability skills in addition to discipline knowledge and technical skills has placed them in a better position to be ready for the continually evolving workplace and society. We will demonstrate this in terms of how it has been strongly linked to students having to respond to the rapid changes during this crisis, highlighting the importance of designing assessment with opportunities to develop the skills needed for lifelong learners for the unknown future.

The paper is structured as follows. We will start with an explanation of the motivation for the integration of employability skills development in assessment practice. This section is followed by an overview of the evolution of the assessment design as we made changes to assessment tasks with the aim of enhancing future accounting graduates' employability outcomes. The paper will then proceed to discuss how and why the focus on employability 
skills integration to assessment led to the development of a student-created video assignment. We then describe how this assignment was adapted and managed in a completely online teaching and learning environment during the COVID-19 lockdown. Finally, we report the preliminary findings on the impact of these changes to student and teaching staff experience; in particular what we have learned about the significance of preparing graduates with skills for the unknown future as experienced during COVID-19. By way of contribution, this paper enables us to share our experiences so that other teaching academics are able to design their own student video assessment task that contributes to the acquisition, development and enhancement of employability skills, such as communication and teamwork skills, that are central in preparing students for continually evolving and unknown future.

\section{Motivation to integrate employability skills development in assessment practice}

The expectation that accounting education integrates a range of employability skills alongside traditional accounting technical skills development is now a very well-established expectation (Bunney et al., 2015). The expectation is driven by the shifts to the accounting profession that is evolving significantly amidst the rapidly and continually changing economy and workplace. Within this changed climate, the role of the professional accountant has changed from a mostly quantitative role to an advisory and consulting role (ACCA, 2016; Behn et al., 2012; Bunney et al., 2015; Daff et al., 2012; Hancock et al., 2009). Thus, the technical skills and the ability to process information as a traditional core focus of accounting education, on their own, are now considered inadequate by the accounting profession to effectively prepare students for the future accounting profession (Tan and Laswad, 2018).

Employability skills refers to those skills beyond accounting discipline knowledge and technical skills and includes skills consistently posited as necessary for a work-ready accounting graduate, that is, analysis, critical thinking, problem-solving, communication (oral 
and written), and teamwork skills (Bui and Porter, 2010; Jackson and Chapman, 2012; Suleman, 2018). These employability skills are both distinct from and complementary to accounting technical skills and play a critical role in the successful application of those technical skills in a rapidly-changing, non-routine and complex business environment (AlphaBeta, 2016; Bennett et al., 2016; Ellington, 2017), and contemporary accounting practice (ACCA, 2016; Hancock et al., 2009). Employers often cite communication skills as being one of the more critical skills needed by accounting graduates (Jackling and Lange, 2009; Kavanagh and Drennan, 2008). In particular, employers believe that accounting graduates often lack verbal communication skills (Gray and Murray, 2011; Jackling and Lange, 2009). In addition, analysis, critical thinking, problem-solving, communication (oral and written), and teamwork skills (Bui and Porter, 2010; Jackson and Chapman, 2012; Radloff et al., 2008; Suleman, 2018) are also considered necessary for a work-ready accounting graduate.

The accounting industry, employers and professional bodies have played significant roles in accounting education reform, reflecting the contemporary accounting profession. This shift is reinforced by professional accounting bodies worldwide that recommend the broadening of the accounting curriculum to include employability skills (Behn et al., 2012; CPA, 2008; Leong and Kavanagh, 2013). Employability skills are also emphasised as important by accounting employers at an international level (Behn et al., 2012; Hancock et al., 2009; Lawson et al., 2014). The Association to Advance Collegiate Schools of Business (AACSB) has also noted that business programs, including accounting, should contain a set of learning outcomes that enables students to demonstrate their acquisition of employability skills alongside accounting technical skills (Hancock et al., 2009).

To understand the disparity between promotion and practice of accounting education and the continued reported skills gap, recent research investigated how accounting academics who are responsible for the design and delivery of assessment in the accounting curriculum 
understand and enact employability skills in the curriculum (Cotronei-Baird, 2020, 2017). The findings indicate that accounting academics hold a common understanding of employability skills that align with the shift in the requirements of the accounting profession and acknowledge that the skills are an important part of teaching and assessment practice (Cotronei-Baird, 2020, 2017). Yet, the observation of practice indicated that employability skills are not systematically and consistently integrated into teaching and assessment practice; with the majority of academics mostly 'discussing' employability skills, with little opportunities for students to develop and enhance the skills in practice. A typology (see Appendix 1) drawn from the findings of the study operates as an indication of the range of levels of integration of employability skills observed in accounting academics' teaching practice. Using the typology, we (two Accounting Academics and a Learning \& Teaching Specialist) analysed the accounting subject curriculum. The main employability skills gap identified included: verbal communication, and teamwork skills as well as the ability to present in a professional manner. This led us to revise the assignments that integrated these employability skills, which in turn lead to the introduction of the student-created video as discussed in the next section.

\section{Integrating employability skills in revised assignments}

The assessments discussed in this paper were developed across two Accounting Information Systems subjects (one undergraduate, one postgraduate) with a focus on business process analysis and internal controls to achieve information quality, which is also the focus of the assignment. The subjects also seek to develop a range of the information technology competencies identified by Pan and Seow (2016), in addition to employability skills. While not the focus of this paper, it highlights how authentic assessment can develop a range of skills.

The first step to the change in the assessment in our subject was the realisation that (at the time) verbal communication was not assessed within the accounting programs at our 
institution. While students were given opportunities to develop these skills as part of the regular class program, there was no formal assessment or feedback provided to students.

To assist in the development of oral communication skills, we introduced a group oral presentation task with live Question and Answer (Q\&A) session into the postgraduate level subject. The inclusion of both live presentation and Q\&A components, enabled us to assess three components of oral communication: presenting, listening and conversing (Brink and Costigan, 2015). The Q\&A component of the assessment task served two purposes. Firstly, to minimise potential group issues around freeriding, with students informed in advance that questions targeted at them were likely to come from parts of the presentation they did not present. And secondly, enabled the assessment of listening and conversing aspects of oral communication which are considered by industry as more important than presenting (Brink \& Costigan, 2015).

This assignment proved successful, and was well-received by students, both in terms of assessing skills they viewed as necessary to develop and requiring them to work in a group. However, the time needed for the grading and giving feedback of both an oral presentation and Q\&A was a challenge as it took up a whole week to grade. The staffing required for marking both employability skills and subject content meant that our resources (staff and time) were stretched; particularly as cohort numbers increased from an initial 150 students, to 300 students.

In seeking to develop a similar assessment at the undergraduate level, we anticipated it would be unfeasible to have the time to listen to, grade and provide formative feedback to all group presentations (minimum of 90 groups, with over 450 students) within the time allowed. This barrier was overcome by making a change to the format of the assignment by considering two important factors. Firstly, an awareness that increasingly students are required to undergo video interviews and produce video CVs as part of graduate recruitment process. Secondly, 
that students have the resources required to create such videos; what student does not have a smartphone or other device with a camera?

\section{The introduction of a student-created video assignment}

An assessment that required students to create a video rather than a live presentation meant that grading and providing timely formative feedback of the video would be possible. The revised assignment format consisted of students submitting a 10-minute video presentation, with a 10minute live Q\&A. Students submitted the video at the start of one week, with the Q\&A conducted in the following week. This new format meant increased flexibility as we did not have to dedicate allocated class time to listen to both the live presentations and Q\&As. The focus was on setting time aside for Q\&A component within a week, with the video being marked independently before the Q\&A session.

The student-created video assessment was designed as a pedagogical technique (Greene, 2014; Tempone et al., 2012; Willmott, 2015). The underlying principle of this approach is on viewing assessment as an opportunity for student learning (Boud and Soler, 2016; Winstone and Boud, 2020), as assessment is one of the most significant influences on students' learning experiences (Boud and Falchikov, 2007). Throughout the entire assessment process - that is from the moment that students plan and work on the assessment and to completion, submission and post-submission, students received ongoing guidance as the premise is that assessment is designed for learning, providing students with the opportunity to learn content and develop the skills necessary beyond the classroom. This was managed through the development and use of a comprehensive assessment rubric that included the identified employability skills and aligned with detailed quality descriptors of the levels of achievement (see Appendix 2). The employability skills included in the rubric were divided among those that assessed the group and individual. The group assessment criteria included: 
visual output, audio output (sound and voice), team cohesion (video), and team cohesion (Q\&A). Individual group members were assessed on the following criteria: presentation skills, language, verbal communication skills and non-verbal communication skills (body language, eye contact and appearance). With the use of the rubric, students were directed to know what they need to do and demonstrate in order to acquire, develop and demonstrate a range of employability skills.

\section{Pivoting online during COVID-19}

While the student-created video assignment was not explicitly developed as a result of COVID19 changes, the skills the assignment sought proved to be significant in response to the university learning experiences and future changes to the workplace as a result of COVID-19. The shift to online teaching, and more importantly work from home for many organisations as a result of COVID-19, justified this form of assessment. Most of our students were studying online for the first time, and the reality of observing their own family and friends working from home demonstrated the range of employability skills required. The student-created video enabled the students to have an authentic opportunity to acquire, develop and demonstrate these skills. For instance, recording a Zoom meeting while sharing a PowerPoint gave students a simple, but effective, way to record the presentation component and thus displaying online presentation skills. The Q\&A session easily transferred to Zoom session enabling students to demonstrate online conversing and listening skills. The design of this assignment made this transition smooth but at the same time enabled students to acquire, develop and demonstrate important skills that will take them into the future. 


\section{How students were supported}

Students were provided with a range of support resources and activities to ensure that they were equipped with the necessary skills to complete the assessment during COVID-19 time. These include the following:

\section{Resources on how to create a video presentation}

While students are not directly taught by teaching staff to create the video presentation, an array of resources such as how to develop a narrated PowerPoint, how to best use smartphone for recording/filming and links to free/open source video editing software were provided. In doing so, students were supported in the process of upskilling on basic yet effective techniques to create video presentation but at the same time given the freedom to explore how to present the given information to the relevant audience. For instance, given the current situation, it was difficult for students to physically get together as a group and in person to produce the video presentation. As such, some students explored the use of Zoom presentation recordings as a means to create a group video presentation as a team despite being in geographically dispersed locations.

\section{Exemplars}

Throughout the semester, teaching materials were developed in a range of video formats, such as narrated PowerPoint, sketch note style video as well as professionally filmed content. While these were not specifically designed to act as exemplars, these videos demonstrated a range of ways information can be presented through video, essentially providing students an 'idea box'.

We also worked with students from a previous semester to create two videos, specifically designed as exemplars. These students turned their previous completed business reports into video format, following the guidelines and rubric. During this process, we received feedback regarding the feasibility and clarity of our guidelines and rubric. The exemplar videos 
were not intended to be perfect, for example, one video presentation demonstrates better team consistency but has poorer individual presentations than the other. They were thus both effective as exemplars and a developmental exercise.

\section{Developmental exercise}

Several weeks prior to the submission of the video presentation, students (individually or in small groups) are asked to assess the exemplar videos, specifically the employability skills, using the assessment rubric. This exercise provided students with the opportunity to assess their peers' performance, become familiar with the key elements of the rubric and take on a marker's perspective to evaluate a presentation. Furthermore, students were able to share their perceptions of how different aspects of the rubric could be demonstrated, which allowed for clarification of the rubric items.

\section{Formative feedback}

One activity that was difficult to carry out in the online mode of learning was the formative feedback exercise. Prior to COVID-19, students (in groups) were provided with opportunities to present Topic Summaries at the start of each class, assessed on the basis of reasonable effort rather than content. The students were able to present in any format of their choice, selecting either a live presentation or a video presentation. General feedback is provided to the whole class allowing subsequent groups to build upon, which in turn provides an exemplar for earlier groups. Teaching staff would provide written formative feedback on the presentations, specifically in the areas of employability skills at the individual level, using a similar rubric to the one used in the video presentation assignment. In doing so, this feedback acts as a way to scaffold and build their employability skills as they approach the video presentation assignment. 
However, with the shift to online teaching as a result of COVID-19, the structure of our online delivery made it difficult from a time management perspective to continue with this exercise. Principally, this was due to reduction in teaching weeks as a result of the shift to online learning, and a change in class format. In saying this, it is not impossible to do, but rather this activity is more difficult to fit into the structure of our course when it is delivered online. This further highlights the importance of the developmental exercise during online learning, as this is the only time when students have the opportunity to apply the marking rubric prior to producing their own.

\section{Support for staff}

By implementing the assessment, staff were required to assess both content and employability skills aspects of the video presentation. Furthermore, separate assessment of employability skills also occurred during the Q\&A sessions. To ensure that this could be carried out effectively and efficiently, teaching staff worked in pairs, with one staff member focusing on assessing employability skills and another staff mainly assessing the content presented in the video. It is important to note that aside from the fact that the Q\&A sessions were carried out through Zoom, much of the marking process remained unchanged with the move to online learning.

Staff were provided with the following resources to support the marking of the video presentation assessment:

\section{Comprehensive rubric and marking guide}

The rubric (Appendix 2) as discussed above, includes both the content and employability skills aspects. Coupled with the marking guide, they provide guidance for the marking of the assignment. 


\section{Marking checklist and marking meeting}

With the nature of the assignment, staff needed to go through the videos prior to conducting the Q\&A session. To ensure that staff were able to ask questions tailored to each video presentation, they were provided with a checklist containing key points of the case study, along with additional questions if certain points are (not) discussed.

A marking meeting was held prior to the start of marking to brief teaching staff with different elements requiring evaluation (i.e. content and employability skills). During the meeting, markers collectively assessed a few video presentations, discussed grading, and established benchmarks, all of which assisted in fostering consistency in marking. Additionally, this provided a unique opportunity for teaching staff to practice writing formative feedback. While some may be accustomed to providing such feedback verbally, with online teaching, this was the first-time staff were asked to put such feedback in writing.

\section{Macro-enable Excel marking spreadsheet}

For this assignment, there are individual and group elements of the marking and feedback. To enable efficient and effective collation and return of marks and feedback to each individual student, including group marks, a macro-enabled Excel spreadsheet was developed. The spreadsheet includes a master sheet that contains a row for each student. The master sheet is populated by macro-enabled forms in which the marks (for each rubric item) and employability feedback of each group and individual students can be entered. This allows for easy collation of information from all markers and a shorter turn-around time for feedback. Students received personalised emails, using mail merge, containing the individual and group grades and feedback; content feedback are returned via the LMS through the video presentation submission tool. 


\section{Findings: Anecdotal feedback from students and staff}

Due to the short rollout period and the pivot to online learning, there has not as yet been an opportunity to undertake a comprehensive and formal data collection of staff and student views of this form of assessment. However, some anecdotal evidence has been collected. Generally, with few exceptions, the student-produced videos were of high quality. Furthermore, there were a range of videos submitted, from the minimum requirements (and rarely done) Zoomrecorded presentations or voice-over PowerPoints, students presenting to camera (the most common) with picture-in-picture presentation, conversational-style and white-board explainer videos. The range of presentations indicated that students considered how they could use video to convey their message better. The videos also provided teaching staff with ideas on how to use videos more effectively in their own teaching practice.

\section{Student feedback}

The most significant feedback received from students focused on the Q\&A session, and how this doubled as a feedback session. The nature of the Q\&A session, in particularly, the use of probing and leading questions helped students consider alternatives to their analysis and recommendations they presented, thus providing a guided learning experience. Students were also provided with general feedback on their performance at the end of the Q\&A session, which provided timely, immediate, feedback to students.

Students indicated that producing a video presentation was less stressful than a live presentation as they have only one opportunity to present well. A video presentation allows rehearsal, review, and reflection and, if necessary, a re-record. This provided a reflection and learning opportunity for students, before submitting, to improve their oral and presentation skills. 
Students also reported that the video presentation was the most authentic "group" assignment that they had undertaken; indicating that coordination and collaboration were needed to ensure that all components of the presentation was covered by the individual presenters, and that visuals, including appearance (such as professional attire) and background (e.g. Zoom backgrounds) were consistent.

\section{Teaching staff feedback}

Staff found this to be an enjoyable and practical marking experience as the nature of the videos meant there was more variation in how students presented the materials when compared to marking the previous written business report. From a staff workload perspective, the marking was set up to be workload "neutral". That is the time taken to grade a business report and deliver a class, was approximately the same as marking the video presentation and live Q\&A. Most importantly, the nature of the immediate feedback provided in the Q\&A session, as discussed above, provided a valuable learning experience (both content and skills acquisition).

The nature of a video presentation was found to also reduce many of the issues associated with group assignments. For example, dominant student issues were not experienced, as it was not possible for a single student to edit or re-film the video without the other students' inputs. Free rider issues are minimised by telling students in advance that during Q\&A they could be asked questions about any part of the video, not just the part they presented. The free rider issues that occurred were obvious during the Q\&A and could be addressed. Both issues were more prevalent in previous forms of group assessment, particularly written assignments, and harder to deal with and prove.

\section{Conclusion}

The accounting profession is continually calling upon universities to embed employability skills within the university curriculum. The impact of COVID-19 has highlighted that the skills 
required by the profession develop and change over time. Therefore, while not an assessment item developed for COVID-19, the rapid change to online, within universities, industry, and society generally because of COVID-19 confirms this to be a pivotal assessment for professional life in an unknown future.

In discussing our experience and sharing our resources, we aim to contribute to the academic community that the development, and assessment of employability skills, such as oral communication and teamwork skills continues to be possible in an online teaching environment. Furthermore, with the increase in work-from-home, the use of video professionally, either through presentations or meetings, is significantly more common, and a skill future accounting graduates need to acquire and enhance.

While we have had to adapt our teaching practices, transitioning from in-class to online, to support this assessment, the very practice of teaching online illustrates to students these employability skills are important and complement their discipline knowledge and skills. Due to the changes that were forced upon us in the transition to online learning, while activities such as the developmental topic summary presentations are more difficult to implement, students are still given formative opportunities to develop these skills through interacting in video conferencing classes. The assessment of these skills has provided students an artifact that can be used to demonstrate these skills, as well as formal feedback for their own development.

For staff, it was a more enjoyable marking experience, both in marking as a team, and in seeing the creativity of students' video presentations, and the interactions that occur within the Q\&A sessions. For students it was a genuine group assignment, with less group issues than other group assignments, and allowed them to develop and reflect on their skills while undertaking the assessment.

In sharing our practice and resources, we hope that you can learn from what we have done and use this as a basis for developing your own video assessment to develop employability 
skills in your students which have become more important as a result of COVID-19. By way of practical contribution, therefore, is on the demonstration of the application of integrating employability skills in assessment practice and the associated rubric as a way to build students' employability skills in the post-COVID-19 world. 


\section{References}

ACCA, 2016. Professional accountants - the future., in: Association of Chartered Certified Accountants.

AlphaBeta, 2016. The new work mindset: 7 new job clusters to help young people navigate the new work order | VOCEDplus, the international tertiary education and research database [WWW Document]. URL https://www.voced.edu.au/content/ngv\%3A74570 (accessed 7.28.20).

Behn, B.K., Ezzell, W.F., Murphy, L.A., Rayburn, J.D., Stith, M.T., Strawser, J.R., 2012. The Pathways Commission on Accounting Higher Education: Charting a National Strategy for the Next Generation of Accountants. Issues in Accounting Education 27, 595-600. https://doi.org/10.2308/iace-10300

Bennett, D., Richardson, S., Mackinnon, P., 2016. Enacting strategies for graduate employability: How universities can best support students to develop generic skills. https://doi.org/10.13140/RG.2.1.4094.8886

Boud, D., Falchikov, N., 2007. Rethinking assessment in higher education: Learning for the longer term, Rethinking assessment in higher education: Learning for the longer term. Routledge/Taylor \& Francis Group, New York, NY, US.

Boud, D., Soler, R., 2016. Sustainable assessment revisited. Assessment \& Evaluation in Higher Education 41, 400-413. https://doi.org/10.1080/02602938.2015.1018133

Brink, K.E., Costigan, R.D., 2015. Oral Communication Skills: Are the Priorities of the Workplace and AACSB-Accredited Business Programs Aligned? Academy of Management learning \& education 205.

Bui, B., Porter, B., 2010. The Expectation-Performance Gap in Accounting Education: An Exploratory Study. Accounting Education 23.

Bunney, D., Sharplin, E., Howitt, C., 2015. Generic skills for graduate accountants: the bigger picture, a social and economic imperative in the new knowledge economy. Higher Education Research \& Development 34, 256-269.

https://doi.org/10.1080/07294360.2014.956700

Cotronei-Baird, V.S., 2020. Academic hindrances in the integration of employability skills development in teaching and assessment practice. High Educ. https://doi.org/10.1007/s10734-019-00405-4

Cotronei-Baird, V.S., 2017. Integrating employability skills into the business curriculum.

CPA, 2008. international-accreditation-guidelines.pdf.

Daff, L., de Lange, P., Jackling, B., 2012. A Comparison of Generic Skills and Emotional Intelligence in Accounting Education. Issues in Accounting Education 27, 627-645. https://doi.org/10.2308/iace-50145

Ellington, P., 2017. The impediments to the change to UK university accounting education, a comparison to the USA pathways commission. Accounting Education 26, 576-598. https://doi.org/10.1080/09639284.2017.1326154

Gray, F.E., Murray, N., 2011. 'A distinguishing factor': Oral Communication Skills in New Accountancy Graduates. Accounting Education 20, 275-294. https://doi.org/10.1080/09639284.2011.560763

Greene, H., 2014. Learning through student created, content videos. International Journal of Arts and Sciences ISSN 1944-6934, 1944-6934.

Hancock, P., Howieson, B., Kavanagh, M., Kent, J., Tempone, I., Segal, N., Freeman, M., 2009. The Roles of Some Key Stakeholders in the Future of Accounting Education in Australia. Australian Accounting Review 19, 249-260.

https://doi.org/10.1111/j.1835-2561.2009.00061.x 
Jackling, B., Lange, D.P.D., 2009. Do Accounting Graduates' Skills Meet The Expectations of Employers? A Matter of Convergence or Divergence. Accounting Education 18, 369-385. https://doi.org/10.1080/09639280902719341

Jackson, D., Chapman, E., 2012. Non-technical competencies in undergraduate business degree programs: Australian and UK perspectives. Studies in Higher Education 541.

Kavanagh, M.H., Drennan, L., 2008. What skills and attributes does an accounting graduate need? Evidence from student perceptions and employer expectations. Accounting \& Finance 48, 279-300. https://doi.org/10.1111/j.1467-629X.2007.00245.x

Lawson, R.A., Blocher, E.J., Brewer, P.C., Cokins, G., Sorensen, J.E., Stout, D.E., Sundem, G.L., Wolcott, S.K., Wouters, M.J.F., 2014. Focusing Accounting Curricula on Students' Long-Run Careers: Recommendations for an Integrated Competency-Based Framework for Accounting Education. Issues in Accounting Education 29, 295-317. https://doi.org/10.2308/iace-50673

Leong, R., Kavanagh, M., 2013. A Work-Integrated Learning (WIL) Framework to Develop Graduate Skills and Attributes in an Australian University's Accounting Program. Asia-Pacific Journal of Cooperative Education 14, 1-14.

Pan, G., Seow, P.-S., 2016. Preparing accounting graduates for digital revolution: A critical review of information technology competencies and skills development. Journal of Education for Business 91, 166-175. https://doi.org/10.1080/08832323.2016.1145622

Radloff, A., Harpe, B., Dalton, H., Thomas, J., Lawson, A., 2008. Assessing graduate attributes: Engaging academic staff and their students. ATN Assessment 1.

Suleman, F., 2018. The employability skills of higher education graduates: insights into conceptual frameworks and methodological options. High Educ 76, 263-278. https://doi.org/10.1007/s10734-017-0207-0

Tan, L.M., Laswad, F., 2018. Professional skills required of accountants: what do job advertisements tell us? Presented at the Accounting education, Taylor \& Francis, Great Britain, p. 403.

Tempone, I., Kavanagh, M., Segal, N., Hancock, P., Howieson, B., Kent, J., 2012. Desirable generic attributes for accounting graduates into the twenty-first century: The views of employers. Accounting Research Journal 25, 41-55.

https://doi.org/10.1108/10309611211244519

Willmott, C.J.R., 2015. Teaching Bioethics via the Production of Student-generated Videos. Journal of Biological Education 49, 127-138. https://doi.org/10.1080/00219266.2014.897640

Winstone, N.E., Boud, D., 2020. The need to disentangle assessment and feedback in higher education. Studies in Higher Education 0, 1-12. https://doi.org/10.1080/03075079.2020.1779687 
Appendix 1: Typology: Accounting academics' observed teaching practice

\begin{tabular}{l|ll}
\hline $\begin{array}{l}\text { Teaching } \\
\text { practice }\end{array}$ & Examples of observed teaching practices \\
\hline $\begin{array}{l}\text { Assesses } \\
\text { employability } \\
\text { skills }\end{array}$ & $\bullet \begin{array}{l}\text { Small range of employability skills are assessed } \\
\text { Gives feedback on small range of employability skills } \\
\text { (analysis and written skills) }\end{array}$ \\
\hline $\begin{array}{l}\text { Facilitates } \\
\text { activities to } \\
\text { apply }\end{array}$ & $\bullet \begin{array}{l}\text { Gives students some practice in application of some } \\
\text { employability skills to case-studies and accounting data } \\
\text { employability } \\
\text { skills }\end{array}$ & $\begin{array}{l}\text { analysis, evaluation, decision-making) } \\
\text { Gives student practice in applying some employability } \\
\text { skills to real life case studies and accounting data. }\end{array}$ \\
\hline $\begin{array}{l}\text { Demonstrates } \\
\text { application of } \\
\text { employability } \\
\text { skills }\end{array}$ & $\bullet \begin{array}{l}\text { Case studies and accounting data used to discuss some } \\
\text { employability skills (analysis, evaluation and decision- } \\
\text { making skills) }\end{array}$ \\
$\begin{array}{l}\text { Shows how to apply some employability skills to real } \\
\text { life case examples and accounting data (analysis, } \\
\text { evaluation and decision-making skills) }\end{array}$ \\
$\begin{array}{l}\text { Discusses } \\
\text { skills }\end{array}$ & $\bullet \begin{array}{l}\text { Mentions some employability skills for the workplace } \\
\text { (analysis evaluation, decision-making, teamwork skills) } \\
\text { Infrequently explains the importance of some } \\
\text { employability skills for the accounting role (analysis, } \\
\text { evaluation, decision-making) }\end{array}$
\end{tabular}


Appendix 2: Assessment Rubric

\begin{tabular}{|c|c|c|c|c|c|}
\hline \multicolumn{6}{|c|}{ VIDEO OUTPUT, AUDIO OUTPUT AND TEAM COHESION } \\
\hline Criteria & Excellent & Good & Acceptable & Poor & Very Poor \\
\hline
\end{tabular}




\begin{tabular}{|c|c|c|c|c|c|}
\hline $\begin{array}{l}\text { Audio } \\
\text { Output } \\
\text { (Sound and } \\
\text { Voice) }\end{array}$ & $\begin{array}{l}\text { Sound is clear, distortion free } \\
\text { and consistent throughout } \\
\text { the presentation. Audio } \\
\text { supports a compelling and } \\
\text { polished presentation. } \\
\text { Language choice, } \\
\text { vocabulary, terminology and } \\
\text { sentence structure are highly } \\
\text { developed, consistent and } \\
\text { highly appropriate to the } \\
\text { topic and the audience. }\end{array}$ & $\begin{array}{l}\text { Sound is mostly clear and } \\
\text { free from distortion free and } \\
\text { consistent throughout the } \\
\text { presentation. Audio supports } \\
\text { a compelling and mostly } \\
\text { polished presentation. } \\
\text { Language choice, } \\
\text { vocabulary, terminology and } \\
\text { sentence structure are } \\
\text { consistent and appropriate to } \\
\text { the topic and audience. }\end{array}$ & $\begin{array}{l}\text { Sound clarity is } \\
\text { understandable with the } \\
\text { distortions that do not } \\
\text { significantly affect the } \\
\text { presentation. Audio supports } \\
\text { the presentation and } \\
\text { interpretation of ideas and } \\
\text { message with some } \\
\text { inconsistencies. } \\
\text { Language choice, vocabulary, } \\
\text { terminology and sentence } \\
\text { structure are mostly consistent } \\
\text { and appropriate to the topic } \\
\text { and audience. }\end{array}$ & $\begin{array}{l}\text { Sound is sometimes unclear } \\
\text { and sometimes distorted and } \\
\text { detracts from the delivering } \\
\text { explicit ideas and message. } \\
\text { Language choice, vocabulary, } \\
\text { terminology and sentence } \\
\text { structure are unclear and lack } \\
\text { explicit alignment to the topic } \\
\text { and audience. }\end{array}$ & $\begin{array}{l}\text { Sound is unclear and } \\
\text { distorted and do not } \\
\text { support the presentation. } \\
\text { Language choice, } \\
\text { vocabulary, terminology } \\
\text { and sentence structure are } \\
\text { not appropriate topic and } \\
\text { audience. }\end{array}$ \\
\hline $\begin{array}{l}\text { Team } \\
\text { Cohesion } \\
\text { (Video) }\end{array}$ & $\begin{array}{l}\text { Effective teamwork is } \\
\text { demonstrated as the video } \\
\text { presentation represents all } \\
\text { team members. High level of } \\
\text { evidence that each member } \\
\text { has a clear role and related } \\
\text { responsibilities. } \\
\text { Natural transition from one } \\
\text { speaker to the next is } \\
\text { demonstrated through } \\
\text { introducing the next } \\
\text { speaker/section of the video } \\
\text { presentation. } \\
\text { Organization of video } \\
\text { presentation is excellent. } \\
\text { The grouping and } \\
\text { sequencing of ideas are } \\
\text { seamless and effectively } \\
\text { supports the message to the } \\
\text { audience. }\end{array}$ & $\begin{array}{l}\text { Mostly effective teamwork is } \\
\text { demonstrated as the video } \\
\text { presentation represents } \\
\text { most of team members. } \\
\text { Mostly very good evidence } \\
\text { that each member has a } \\
\text { clear role and related } \\
\text { responsibilities. } \\
\text { Mostly natural transition from } \\
\text { one speaker to the next is } \\
\text { demonstrated through } \\
\text { introducing the next } \\
\text { speaker/section of the video } \\
\text { presentation. } \\
\text { Organization of video } \\
\text { presentation is good to very } \\
\text { good. The grouping and } \\
\text { sequencing of ideas are } \\
\text { mostly seamless and } \\
\text { support the message to the } \\
\text { audience. }\end{array}$ & $\begin{array}{l}\text { Effective teamwork is not } \\
\text { always consistently } \\
\text { demonstrated as the video } \\
\text { presentation does not always } \\
\text { explicitly represents all team } \\
\text { members. Some evidence that } \\
\text { each member has a clear role } \\
\text { and related responsibilities. } \\
\text { Adequate transition from one } \\
\text { speaker to the next is } \\
\text { demonstrated - some } \\
\text { inconsistencies observed in } \\
\text { the introductions to the next } \\
\text { speaker/section of the video } \\
\text { presentation. } \\
\text { Organization of video } \\
\text { presentation is satisfactory. } \\
\text { The grouping and sequencing } \\
\text { of ideas support the message } \\
\text { to the audience. }\end{array}$ & $\begin{array}{l}\text { Minimal evidence of effective } \\
\text { teamwork demonstrated as the } \\
\text { video presentation does not } \\
\text { represents all team members. } \\
\text { Minimal evidence that each } \\
\text { member has a clear role and } \\
\text { related responsibilities. } \\
\text { Minimal transition from one } \\
\text { speaker to the next. } \\
\text { Improvements required so that } \\
\text { the next speaker/section of the } \\
\text { video presentation are } \\
\text { consistently introduced. } \\
\text { Undeveloped organization of } \\
\text { video presentation. The } \\
\text { grouping and sequencing of } \\
\text { ideas do not consistently } \\
\text { support the message to the } \\
\text { audience. }\end{array}$ & $\begin{array}{l}\text { No evidence of effective } \\
\text { teamwork demonstrated. } \\
\text { No evidence that each } \\
\text { member has a clear role } \\
\text { and related responsibilities. } \\
\text { No transition from one } \\
\text { speaker to the next } \\
\text { Unsatisfactory video } \\
\text { presentation organization. }\end{array}$ \\
\hline
\end{tabular}




\begin{tabular}{|l||l|l|l|l|}
\hline $\begin{array}{l}\text { Team } \\
\begin{array}{l}\text { Cohesion } \\
\text { (Question \& } \\
\text { Answer) }\end{array}\end{array}$ & $\begin{array}{l}\text { Clear evidence of team } \\
\text { cohesion during the Q\&A } \\
\text { session by maintaining the } \\
\text { identity of the team* } \\
\text { throughout the process. }\end{array}$ & $\begin{array}{l}\text { Mostly good to very good } \\
\text { evidence of team cohesion } \\
\text { during the Q\&A session by } \\
\text { maintaining the identity of } \\
\text { the team* throughout the } \\
\text { process. }\end{array}$ & $\begin{array}{l}\text { Evidence of team cohesion } \\
\text { during the Q\&A is } \\
\text { demonstrated. Some } \\
\text { inconsistencies in maintaining } \\
\text { team identity* is observed. }\end{array}$ & $\begin{array}{l}\text { Team cohesion during the } \\
\text { Q\&A session is not explicit as } \\
\text { identity of the team* } \\
\text { throughout the process is } \\
\text { lacking. }\end{array}$ \\
\hline \hline
\end{tabular}

*Visual aids: Can include appropriate use of illustrations, graphics (e.g. appropriately-sized flowcharts), bulleted information, animations, among other media; the visual aid should enhance the delivery of the communication, oral and/or visual by providing clarification, amplification, emphasis or support to the principal ideas and general purpose of the presentation.

*Team identity: Team identity needs to be built and developed as you work through the project and demonstrated via all parts of the assessment. Some evidence on how to demonstrate this is by using the pronoun "we" in expressing ideas and supporting each other during the video presentation/Q\&A session. 
INDIVIDUAL

\begin{tabular}{|c|c|c|c|c|c|}
\hline Criteria & Excellent & Good & Acceptable & Poor & Very Poor \\
\hline \multicolumn{6}{|c|}{ COMMUNICATION SKILLS: VIDEO DELIVERY } \\
\hline $\begin{array}{l}\text { Presentation } \\
\text { skills }\end{array}$ & $\begin{array}{l}\text { Consistently high level of } \\
\text { clear speech and concise } \\
\text { message delivery. } \\
\text { Appropriate pace. Always } \\
\text { uses an appropriate and } \\
\text { confident tone to deliver the } \\
\text { intended message, including } \\
\text { vocal expressiveness, on } \\
\text { camera engagement", diction, } \\
\text { and enunciation. } \\
\text { Uses voice expressively, and } \\
\text { uses few vocal fillers ("um," } \\
\text { "uh," "like," "you know," etc.). } \\
\text { Speaker's energy and } \\
\text { emphases is evident in } \\
\text { delivery - enhances } \\
\text { interpretation of ideas, } \\
\text { responses or message } \\
\text { expressed. } \\
\text { Engagement with audiences } \\
\text { is professional, conversational } \\
\text { and persuasive, which } \\
\text { commands the interest and } \\
\text { attention of the audience. } \\
\text { Dependency upon notes is } \\
\text { not evident. } \\
\text { Professional attire. }\end{array}$ & $\begin{array}{l}\text { Good to very good speech and } \\
\text { concise message delivery. } \\
\text { Mostly appropriate pace. } \\
\text { Always uses good tone to } \\
\text { deliver the intended message, } \\
\text { including vocal expressiveness, } \\
\text { on camera engagement", } \\
\text { diction, and enunciation. } \\
\text { Mostly good to very good voice } \\
\text { expression with few vocal fillers } \\
\text { ("um," "uh," "like," "you know," } \\
\text { etc.). Speaker's energy and } \\
\text { emphases is good - mostly } \\
\text { fosters interpretation of ideas, } \\
\text { responses or message } \\
\text { expressed. } \\
\text { Engagement with audiences is } \\
\text { mostly professional, } \\
\text { conversational and persuasive, } \\
\text { which aids in holding the } \\
\text { interest and attention of the } \\
\text { audience. } \\
\text { Dependency on notes is not } \\
\text { intrusive. } \\
\text { Professional attire. }\end{array}$ & $\begin{array}{l}\text { Speech and message delivery } \\
\text { are satisfactory - some } \\
\text { improvement required in } \\
\text { ensuring that appropriate and } \\
\text { confident tone to deliver the } \\
\text { intended message, including } \\
\text { vocal expressiveness, on } \\
\text { camera engagement", diction, } \\
\text { and enunciation is enhanced. } \\
\text { Satisfactory voice expression } \\
\text { with some noticeable } \\
\text { enunciation and vocal fillers } \\
\text { ("um," "uh," "like," "you know," } \\
\text { etc.) issue. Speaker's energy } \\
\text { and emphases in delivery assist } \\
\text { in interpretation of ideas, } \\
\text { responses or message } \\
\text { expressed. } \\
\text { Engagement with the audiences } \\
\text { is appropriate. Improvement } \\
\text { required to ensure that the } \\
\text { message is more professional, } \\
\text { conversational and persuasive. } \\
\text { Dependency on notes is } \\
\text { noticeable but does not } \\
\text { significantly impact presentation. } \\
\text { Mostly professional attire. }\end{array}$ & $\begin{array}{l}\text { Undeveloped quality speech } \\
\text { and delivery of message. Pace } \\
\text { requires improvement; often } \\
\text { spoke in a monotonous way } \\
\text { and tone does not reflect the } \\
\text { intended message, including } \\
\text { vocal expressiveness, on } \\
\text { camera engagement*, diction, } \\
\text { and enunciation. Being mindful } \\
\text { of appropriate } \\
\text { pauses/hesitations. } \\
\text { Undeveloped voice } \\
\text { expression, and uses too } \\
\text { many vocal fillers ("um," "uh," } \\
\text { "like," "you know," etc.). } \\
\text { Speaker demonstrates low } \\
\text { level of energy and emphases. } \\
\text { Undeveloped engagement with } \\
\text { audience; which detracts from } \\
\text { holding the interest and } \\
\text { attention of the audience. } \\
\text { Highly dependent on notes; } \\
\text { sounds like the presentation is } \\
\text { mostly read. } \\
\text { Non-professional attire. }\end{array}$ & $\begin{array}{l}\text { Unsatisfactory and unclear } \\
\text { speech. Pace and tone are } \\
\text { inappropriate and distract from } \\
\text { sending the intended } \\
\text { message, including vocal } \\
\text { expressiveness, on camera } \\
\text { engagement", diction, and } \\
\text { enunciation. } \\
\text { Unsatisfactory voice } \\
\text { expressions and overuse of } \\
\text { vocal fillers ("um," "uh," "like," } \\
\text { "you know," etc.). Speaker } \\
\text { lacks energy and emphases. } \\
\text { Unsatisfactory engagement } \\
\text { with audiences. } \\
\text { Always dependent upon } \\
\text { notes. } \\
\text { Non-professional attire. }\end{array}$ \\
\hline
\end{tabular}




\begin{tabular}{|c|c|c|c|c|c|}
\hline Language & $\begin{array}{l}\text { Language enhances the } \\
\text { effectiveness of the } \\
\text { presentation - is } \\
\text { compelling, vivid, and } \\
\text { expressive. It enhances the } \\
\text { expression of ideas and } \\
\text { contributes to meaningful } \\
\text { audience interpretation. }\end{array}$ & $\begin{array}{l}\text { Language mostly enhances } \\
\text { the effectiveness of the } \\
\text { presentation - is mostly } \\
\text { compelling, vivid, and } \\
\text { expressive to support the } \\
\text { expression of ideas and } \\
\text { contributes to meaningful } \\
\text { audience interpretation. }\end{array}$ & $\begin{array}{l}\text { Language choices are } \\
\text { appropriate and support the } \\
\text { presentation and expression } \\
\text { of ideas and contributes to } \\
\text { audience interpretation. }\end{array}$ & $\begin{array}{l}\text { Language is undeveloped } \\
\text { and minimally support the } \\
\text { effectiveness of the } \\
\text { presentation. Language } \\
\text { appropriateness is } \\
\text { inconsistent. Expression of } \\
\text { ideas is hindered. }\end{array}$ & $\begin{array}{l}\text { Language choices are } \\
\text { unclear and fail to support } \\
\text { the effectiveness of the } \\
\text { presentation. Language is } \\
\text { not appropriate to } \\
\text { audience; ideas are not } \\
\text { expressed clearly. }\end{array}$ \\
\hline \multicolumn{6}{|c|}{ QUESTIONS AND ANSWERS } \\
\hline $\begin{array}{l}\text { Verbal } \\
\text { communication } \\
\text { skills: } \\
\text { Responses and } \\
\text { contribution }\end{array}$ & $\begin{array}{l}\text { Always listens to the } \\
\text { question carefully and } \\
\text { considers the question } \\
\text { before answering. } \\
\text { The answers address the } \\
\text { questions, are always } \\
\text { relevant and concisely draw } \\
\text { from the case/presentation } \\
\text { when needed. } \\
\text { Consistently responds in a } \\
\text { professional manner when } \\
\text { challenged - asks } \\
\text { questions for clarification, } \\
\text { demonstrates honesty and } \\
\text { clear to the point. } \\
\text { Readily able to adapt } \\
\text { recommendations or KPIs } \\
\text { presented when } \\
\text { challenged. }\end{array}$ & $\begin{array}{l}\text { Mostly good listening } \\
\text { techniques demonstrated } \\
\text { with good consideration of } \\
\text { the question before } \\
\text { answering. } \\
\text { The answers mostly address } \\
\text { the questions, are mostly } \\
\text { relevant and draw from the } \\
\text { case/presentation when } \\
\text { needed. } \\
\text { Responds in a professional } \\
\text { manner when challenged - } \\
\text { asks questions for } \\
\text { clarification, demonstrates } \\
\text { honesty and clear to the } \\
\text { point. } \\
\text { Mostly good to very good } \\
\text { ability to adapt } \\
\text { recommendations or KPls } \\
\text { presented when challenged. }\end{array}$ & $\begin{array}{l}\text { Satisfactory listening } \\
\text { techniques demonstrated with } \\
\text { acceptable consideration of } \\
\text { the question before } \\
\text { answering. } \\
\text { The answers satisfactorily } \\
\text { address some of the } \\
\text { questions, and occasionally } \\
\text { draw from the } \\
\text { case/presentation. } \\
\text { Mostly responds in a } \\
\text { professional manner when } \\
\text { challenged - occasionally } \\
\text { asks questions for } \\
\text { clarification. } \\
\text { Recognises the need to adapt } \\
\text { recommendations or KPls } \\
\text { presented when challenged. }\end{array}$ & $\begin{array}{l}\text { Undeveloped listening } \\
\text { techniques demonstrated } \\
\text { with minimal consideration of } \\
\text { the question before } \\
\text { answering. } \\
\text { Demonstrates difficulty in } \\
\text { ensuring that answers } \\
\text { address the questions and } \\
\text { there is minimal reference to } \\
\text { case/presentation. } \\
\text { Responses lack } \\
\text { professionalism when } \\
\text { challenged - does not asks } \\
\text { questions for clarification. } \\
\text { Limited recognition of the } \\
\text { need to adapt } \\
\text { recommendations or KPIs } \\
\text { presented when challenged. }\end{array}$ & $\begin{array}{l}\text { Unsatisfactory listening } \\
\text { techniques demonstrated } \\
\text { with no or irrelevant } \\
\text { consideration of the } \\
\text { question before answering. } \\
\text { Unable to answer } \\
\text { questions. } \\
\text { Unable to respond in a } \\
\text { professional manner when } \\
\text { challenged - does not asks } \\
\text { questions for clarification. } \\
\text { Does not recognise the } \\
\text { need to adapt } \\
\text { recommendations or KPIs } \\
\text { presented when } \\
\text { challenged. }\end{array}$ \\
\hline
\end{tabular}




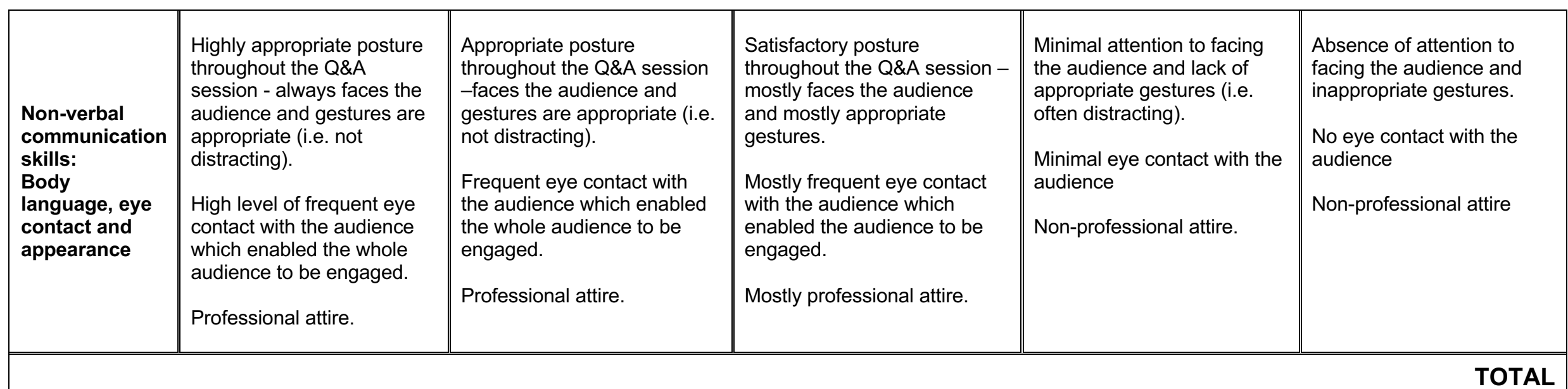




\section{University Library}

\section{- M M N E R VA A gateway to Melbourne's research publications}

Minerva Access is the Institutional Repository of The University of Melbourne

Author/s:

Dyki, M;Singorahardjo, M;Cotronei-Baird, VS

Title:

Preparing graduates with the employability skills for the unknown future: reflection on assessment practice during COVID-19

Date:

2020-12-03

\section{Citation:}

Dyki, M., Singorahardjo, M. \& Cotronei-Baird, V. S. (2020). Preparing graduates with the employability skills for the unknown future: reflection on assessment practice during COVID-19. ACCOUNTING RESEARCH JOURNAL, 34 (2), pp.229-245. https:// doi.org/10.1108/ARJ-09-2020-0285.

Persistent Link:

http://hdl.handle.net/11343/252771 